\title{
Thailand Insurance Regulation: Highlights \& Time to Go Ahead
}

\author{
Sivalap Sukpaiboonwat ${ }^{1}$, Chucheep Piputsitee ${ }^{1} \&$ Arunee Punyasavatsut ${ }^{1}$ \\ ${ }^{1}$ Faculty of Economics, Kasetsart University, Bangkok, Thailand \\ Correspondence: Sivalap Sukpaiboonwat, Faculty of Economics, Kasetsart University, Bangkok, Thailand. \\ E-mail: sivalap@gmail.com
}

Received: October 12, 2013 Accepted: January 29, 2014 Online Published: February 26, 2014

doi:10.5539/ass.v10n6p24

URL: http://dx.doi.org/10.5539/ass.v10n6p24

\begin{abstract}
This paper presents Thailand's insurance regulatory highlights and compares with 15 Asian countries. The comparison focuses on government regulators, minimum capital requirements, solvency regulation, policyholder protection fund and foreign ownership restrictions. Because of different complexity in insurance business and economic culture in each countries, the policymakers appoint insurance regulator who works under various departments, different from country to country, such as The Ministry of Finance (Brunei Darussalam, Cambodia, Indonesia, Laos, Myanmar, the Philippines, Vietnam, and Thailand), a Central Bank (Malaysia, and Singapore), and some other Government Agencies (China, Japan, Taiwan, South Korea, and Hong Kong). For licensed insurers, the highest minimum paid-up capital is USD52 million in Taiwan, and the lowest paid-up capital is USD1 million in Hong Kong due to Hong Kong liberalizing insurance market requiring no restriction in investment. Risk Based Capital has been evolving rapidly across Asian countries particularly in Japan, Indonesia, Taiwan, Singapore, Malaysia, South Korea, The Philippines and Thailand. The protection funds for policyholders in the event of insurer insolvency were already established in most countries except Cambodia and Laos, who require deposit protection fund with local government. Regarding foreign ownership regulation, there are no restrictions in Hong Kong, Japan, South Korea, Brunei Darussalam, Cambodia, the Philippines, Singapore, and Vietnam; whilst other countries, namely China, Taiwan, Indonesia, Laos, Malaysia, Myanmar, and Thailand, gradually release the market access restrictions. In assessing insurance regulation, this is helpful for understanding the current insurance legislation and future development for Thailand insurance regulation.
\end{abstract}

Keywords: government regulator, minimum capital requirement, solvency regulation, policyholder protection fund, foreign ownership restriction

\section{Introduction}

Insurance is a contract between two parties as insurer and insured. The first party is the insurer, including insurance companies must pay amount of compensation to the other party is insured or beneficiaries may be specified in the contract when the insured gets loss of life or capital resource. While the second party is the insured must pay the insurance premium to the insurer for this coverage. The rational for government regulation because insurance is intangible nature, only promise. Regulator must to ensure the insurer's ability to pay claims in the future.

There are some studies about regulations in the insurance industry. Ziv-Av (2006) studies the relationship between the insurance regulation policy and the market competition in the United States, the European Union and Israel. The study finds that regulation development will effect competition enhancement. Schuckmann (2007) considers the impact of regulatory measures on insurance market competition in European Union. The study finds that three sources of imperfection in insurance market are asymmetrically distributed information, externalities, and inadequate competition. Based on the imperfections, Solvency II rules will be useful in alleviating the adverse effects of market distortions. The rules provide a signal to insurer as well as consumer, to monitor quality insurance companies and increase understanding of the risks within insurance companies. Asymmetric information will be reduced and the customers are better-informed in selecting an insurer.

For Thailand, there are no studies that demonstrating insurance regulation especially in government regulators, minimum capital requirements, solvency regulation, policyholder protection fund and foreign ownership restrictions. So this study will investigate the framework of insurance regulation in Thailand and 15 Asian countries, specifically those in East Asia and Southeast Asia. It is helpful to have an understanding of the current 
regulation of the insurance industry and consider their future paths. This study is organized as follows: Section 2 uses qualitative research for insurance regulation; Section 3 presents results which compares insurance regulatory in Asian countries and analyses Thailand regulation highlights; then Section 4 conclusion of the study.

\section{Method}

The government regulates the insurance industry by using the practice of rules that insurers must abide by. For examples, the regulator often sets the minimum capital for entry barriers, conducts rigorous monitoring of insurer activities with solvency margin or risk based capital (RBC), and sets policyholder protection funds to provide certain protection for policyholders in the event of insurer insolvency. Moreover, many countries have liberalized the market, thus permitting foreign insurers to operate in the domestic insurance market.

For understanding insurance regulatory environment in Asia, this paper use qualitative research by comparison analysis of insurance regulation. This paper considers two groups of Asian economies, totally 15 countries, which are East Asia and Southeast Asia. The five East Asian countries are China, Hong Kong, Taiwan, Japan and South Korea. The ten Southeast Asian countries are Brunei Darussalam, Cambodia, Indonesia, Laos, Malaysia, Myanmar, the Philippines, Singapore, Vietnam and Thailand, which are all ASEAN member countries. This paper looks in five sections in each country.

a) The first section deals with government regulator monitoring, supervising, promoting and administrating the insurance industry.

b) The second section looks at market access regulation in term of minimum capital requirements for insurance company.

c) The third section describes the solvency regulation that licensed insurers in the country must abide by.

d) The fourth section summarizes market conduct regulation with policyholder protection fund.

e) The last section considers market liberalization through foreign ownership restrictions.

\section{Results}

\subsection{Comparison Analysis of Insurance Regulation}

Table 1. Asian insurance regulatory environment as of 2012

\begin{tabular}{|c|c|c|c|c|c|}
\hline $\begin{array}{l}\text { Government } \\
\text { Regulators }\end{array}$ & $\begin{array}{l}\text { Minimum Capital } \\
\text { Requirements }\end{array}$ & Solvency Regulation & $\begin{array}{l}\text { Policyholder } \\
\text { Protection } \\
\text { (PPF) }\end{array}$ & Fund & $\begin{array}{l}\text { Foreign } \\
\text { Ownership } \\
\text { Restrictions }\end{array}$ \\
\hline
\end{tabular}

\section{China}

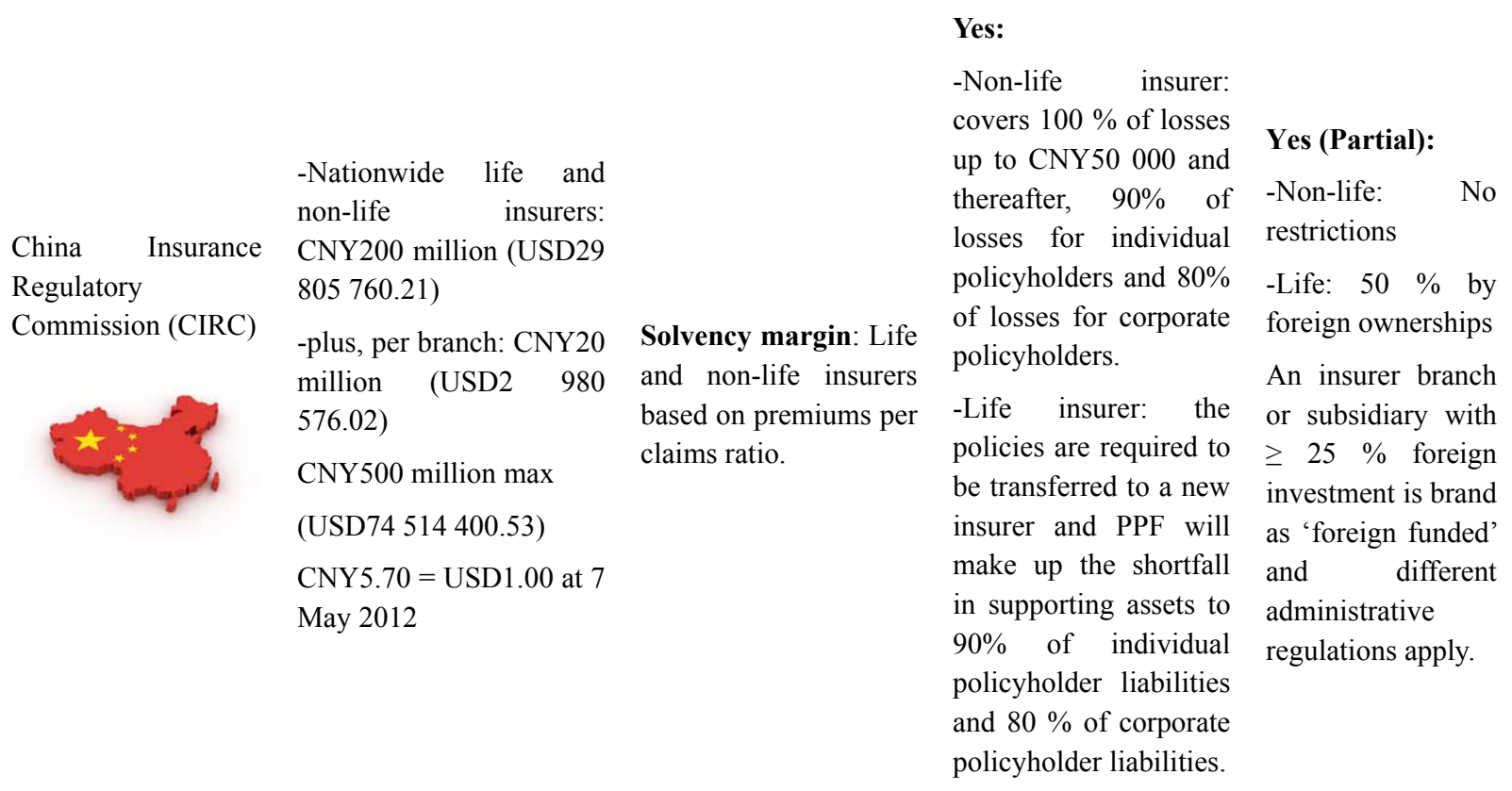




\begin{tabular}{|c|c|c|c|c|c|}
\hline $\begin{array}{l}\text { Government } \\
\text { Regulators }\end{array}$ & $\begin{array}{l}\text { Minimum Capital } \\
\text { Requirements }\end{array}$ & Solvency Regulation & $\begin{array}{l}\text { Policyholder } \\
\text { Protection } \\
\text { (PPF) }\end{array}$ & Fund & $\begin{array}{l}\text { Foreign } \\
\text { Ownership } \\
\text { Restrictions }\end{array}$ \\
\hline
\end{tabular}

\section{Hong Kong}

The Insurance Authority (IA)

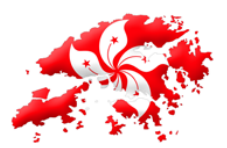

-Life and non-life insurers: HKD10 million (USD1 249 162.75)

-Composite insurers: HKD20 million (USD2 498 325.51)

HKD7.24 = USD1.00 at 7 May 2012

\section{Solvency margin:}

Non-life insurer: the greater between 1) and 2)

1) $1 / 5$ of relevant premium income up to HKD200 million + $1 / 10$ of the amount by which the relevant premium income exceeds HKD200 million

2) $1 / 5$ of relevant outstanding claims up to HKD200 million + $1 / 10$ of the amount by which the relevant outstanding claims exceed HKD200 million, subject to a minimum of HKD10 million (HKD20 million for certain statutory classes).

Life insurer: the greater of HKD2 million and $4 \%$ of mathematical reserves $+0.3 \%$ of capital at risk.

RBC: The adoption of a new RBC system for Hong Kong is expected to be set up in 2013 or 2014.

\section{Taiwan}

Financial Supervisory Commission (FSC).

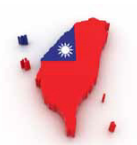

Life and non-life insurers: TWD2 billion (USD52 913 596.78), $20 \%$ to be paid at the time of application.

TWD25.42 = USD1.00 at 7 May 2012
RBC: Insurers maintain a ratio of total adjusted net capital to its risk-based capital requirement of at least $200 \%$.

Solvency II: Now, Taiwan has been studying Solvency II.
Yes:

The Stabilization Fund is a private organization, sponsored by insurance companies, and is established to stabilize the market and safeguard the interests of insured parties.
No:

Foreign companies may acquire any percentage of the shares in an existing insurance company or establish branches, or locally incorporate subsidiaries.
Yes:

A foreign insurance enterprise must be granted investment permission from the relevant authority. 


\begin{tabular}{|c|c|c|c|c|c|}
\hline $\begin{array}{l}\text { Government } \\
\text { Regulators }\end{array}$ & $\begin{array}{l}\text { Minimum Capital } \\
\text { Requirements }\end{array}$ & Solvency Regulation & $\begin{array}{l}\text { Policyholder } \\
\text { Protection } \\
\text { (PPF) }\end{array}$ & Fund & $\begin{array}{l}\text { Foreign } \\
\text { Ownership } \\
\text { Restrictions }\end{array}$ \\
\hline
\end{tabular}

\section{Japan}

Financial Services Agency of the Japanese Government (FSA)

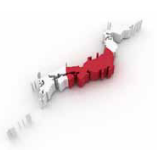

-Life and non-life insurers: JPY1 billion (USD9 849 296.71)

$\begin{array}{ll}\text {-Licensed } & \text { Foreign } \\ \text { Insurers: add up } & \end{array}$

JPY200 million (USD1 969859.34)

JPY92.95 = USD1.00 at 7 May 2012

\section{South Korea}

The Financial

Services

Commission (FSC) and The Financial Supervisory Service (FSS)

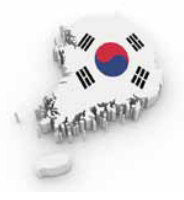

6.

Brunei

\section{Darussalam}

The Autoriti

Monetari Brunei

Darussalam

(AMBD)

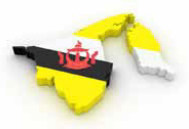

7. Cambodia

The Insurance

Division of the

Financial Industry

Department (FID)
-Life and non-life insurers: KRW5 billion (USD4 135 967.84)

-Composite insurers: KRW30 billion (USD24 815807.09 )

KRW924.67 = USD 1.00 at 7 May 2012

Life and non-life insurers: BND8 million (USD 6183523.10 USD) BND1.17 = USD1.00 at 7 May 2012

-Life and non-life insurers: SDR5 million (USD7.55 million)

-Composite insurers: SDR10 million (USD15.1
Solvency margin: Insurer must keep at least $200 \%$.

Solvency margin ratio $(\%)=$

(Total amount of solvency margin divided by Total amounts of risks $\mathrm{x} 1 / 2$ ) $\mathrm{x} 100$

Solvency II: FSA plans to introduce new regulation similar to the EU's Solvency II regime

\section{Solvency margin:} Insurer must maintain solvency margin of at least $100 \%$.

RBC: $\mathrm{RBC}$ rules have been in effect since 1 April 2011.

Solvency II: FSS plans enhancements of $\mathrm{RBC}$ and the internal model which similar to EU Solvency II standards.

Solvency margin: Insurer should maintain $20 \%$ solvency margin based on premium income.

Solvency margin: The required solvency margin varies depending on number of years in operation and premium amount.
Yes:

There are two No: policyholder protection corporations:

-Life Insurance:

Policyholders

Protection Corporation of Japan

-Non-Life Insurance: Policyholders

Protection Corporation of Japan

Yes:

There is policyholder protection fund in South Korea namely The Korea Deposit Insurance Corporation (KDIC) which maintains a deposit insurance fund.

No:

Foreign insurers are allowed to establish branches or subsidiaries in Korea and to buy any percentage of a domestic company's equity.
Yes:

There is policyholder protection fund in Brunei.
No:

The Insurance Order 2006 and Insurance

Regulations 2006 do not restrict or discriminate against foreign participation

No:

There is no separate protection fund for policyholders.

However, the insurer must maintain a
No:

Local insurance companies may be fully owned $100 \%$ by foreign 


\begin{tabular}{ll}
\hline Government & $\begin{array}{l}\text { Minimum Capital } \\
\text { Requirements }\end{array}$ \\
Regulators & million) \\
& SDR = IMF special \\
drawing rights. \\
As at 7 May 2012 SDR 1 \\
$=$ USD1.51 \\
-Micro-insurance \\
insurers: KHR600 million \\
(USD150 562.14) \\
KHR3985.07 = USD 1.00 \\
at 7 May 2012
\end{tabular}

\section{Indonesia}

The Insurance Life and non-life Bureau at the insurers: IDR 70 billion Ministry of Finance in 2012 (USD5 462 (MOF)

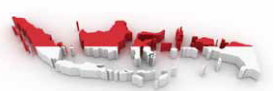
156.73 USD) and expected 100 billion in 2014 (USD7 803081.04 USD)

IDR8279.06 = USD 1.00 at 7 May 2012

\section{Laos}

The Ministry of

Finance(MOF)

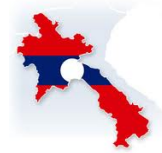

N.A.

\section{Malaysia}

Bank Negara

Malaysia (BNM)

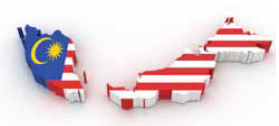

Operating life and non-life insurers: RM100 million (USD31 580 709.97)

No new operating license available for new insurers.

RM2.79 $=$ USD1.00 at 7 May 2012

\section{Myanmar}

The Insurance Business Supervisory Board
N.A.

RBC solvency margin ratio:

Insurer must keep Solvency Margin Ratio of at least $100 \%$.

Solvency Margin

Ratio:

$=$ net asset value (book value) divided by net asset value recalculated

Yes:

Each insurance company must form its own protection fund to protect the interests of policyholders.

\section{No:}

There is no separate protection fund for policyholders.

However, the insurer must maintain a deposit to the National Treasury.

RBC: BNM has set a Target Capital Available Level of $130 \%$.

Capital Adequacy Ratio $(\mathrm{CAR})=$

(Total capital available divided by Total capital required) $\mathrm{x}$ $100 \%$
Yes:

The Malaysia Deposit Insurance Corporation (MIDC) administers the Takaful and Insurance Benefits Protection System (TIPS) which protects specific benefits under life and general insurance.
Foreign

Ownership

Restrictions

investors.

thes.
Yes:

Foreign shareholders of any entity carrying insurance activities are limited to $80 \%$ at establishment.
Yes:

A foreign insurance company must be authorized by the Lao government.
Yes:

Foreign ownerships generally limited to $70 \%$. The amount exceeding $70 \%$ can be approved by the $\mathrm{BNM}$ on a case by case.
Solvency margin: Capital requirements are based on a

\section{Yes (Partial):}

Insurers must establish
Yes:

Foreign investment 


\begin{tabular}{ll}
\hline Government & Minimum Capital \\
Regulators & Requirements \\
\hline (IBSB) & -Non-life insurers: \\
MMK200 million \\
(USD223 588.31) \\
In 2015 to be increased \\
-Life insurers: MMK6 \\
billion \\
(USD 6 707 649.30) \\
-Non-life \\
MMK40 billion (USD44 \\
717 662.03) \\
-Mixed insurers: MMK46 \\
billion (USD51 425 \\
311.33) \\
MMK894.50 = USD1.00 \\
at 7 May 2012
\end{tabular}

12. The Philippines

The Insurance

Commission of the

Philippines (IC)

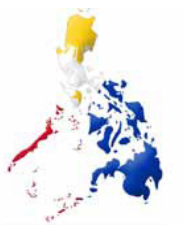

Monetary Authority of Singapore (MAS)

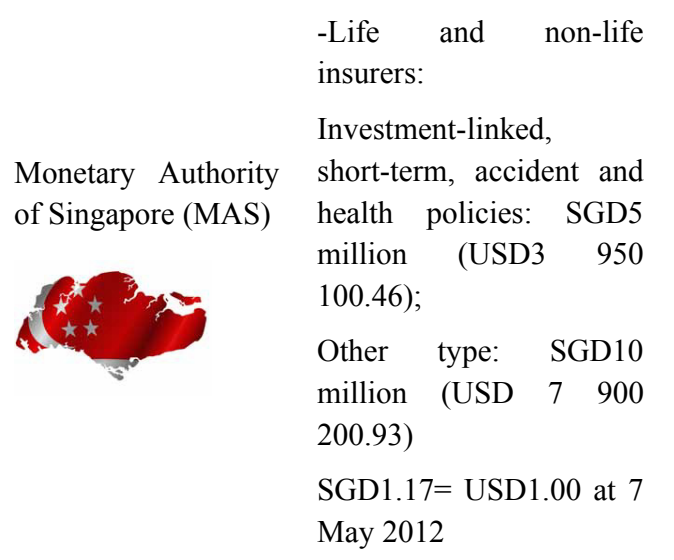

13. Singapore

Life and non-life insurers: PHP250 million in 2012 (USD4 186 202.27) and expected PHP400 million in 2014 (USD6 697 923.64), PHP600 million in 2016 (USD10 046 885.46), PHP800 million in 2018 (USD13 395 847.28) and PHP1 billion in 2020 (USD16 744 809.10). PHP36.51 = USD1.00 at 7 May 2012
RBC: Insurer must maintain $\mathrm{RBC}$ ratio requirements.
Yes:

There is policyholder protection fund in The Philippines.

\section{Foreign \\ Ownership \\ Restrictions}

is not permitted in the insurance sector, subject to government approval. The restriction may be relaxed in 2015 .
No:

Foreign ownership is permitted under the Republic Act No 8170, 1996, of up to $100 \%$ ownership.
RBC: Total Risk Requirements (TRR) is imposed insurers.

Solvency II: Now, Singapore has been studying Solvency II.

\section{Vietnam}

The Insurance Supervisory Authority (ISA)
-Life insurers: VND600 billion (USD21 098 459.47)
Solvency margin: Yes:

Insurer must maintain adequate solvency
Yes:

Policy Owners' Protection Scheme (PPF Scheme) has been set up to protect policy owners in the event of failure of a life or general insurer which is a member of Policy Owners' Protection Scheme.

\section{No:}

There are no restrictions on the level of foreign ownership. 


\begin{tabular}{lllll}
\hline $\begin{array}{l}\text { Government } \\
\text { Regulators }\end{array}$ & $\begin{array}{l}\text { Minimum Capital } \\
\text { Requirements }\end{array}$ & Solvency Regulation & $\begin{array}{l}\text { Policyholder } \\
\text { Protection } \\
\text { (PPF) }\end{array}$ & $\begin{array}{l}\text { Foreign } \\
\text { Ownership } \\
\text { Festrictions }\end{array}$ \\
\hline & -Non-life insurers: & $\begin{array}{l}\text { margin not less than } \\
\text { the minimum solvency } \\
\text { margin }\end{array}$ & $\begin{array}{l}\text { Vietnam which was } \\
\text { introduced on 1 July }\end{array}$ & 2011. \\
& VND300 billion ownership. & & \\
& VND10 549 229.73) & & \\
& USD1.00 at 7 May 2012 & &
\end{tabular}

15. Thailand

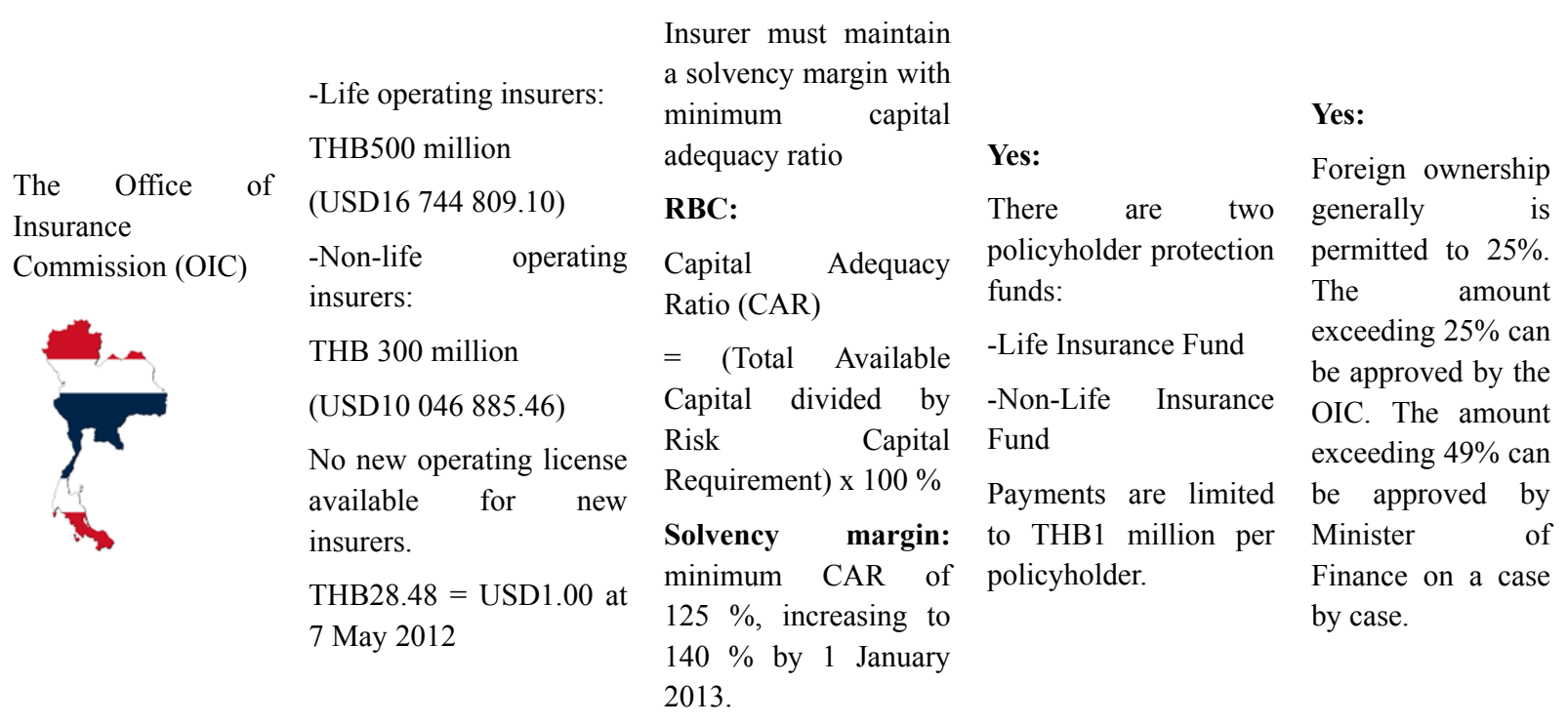

Source: Compared by author, using data from Norton Rose Fulbright and Office of Insurance Commission

As shown in Table 1, the different complexity in insurance business and economic culture in each countries so the policymakers appoint insurance regulator who works under various departments, different from country to country, such as The Ministry of Finance (The Autoriti Monetari Brunei Darussalam, The Insurance Division of the Financial Industry Department of Cambodia, The Insurance Bureau at the Ministry of Finance in Indonesia, The Ministry of Finance in Laos, The Insurance Business Supervisory Board of Myanmar, The Insurance Commission of the Philippines, The Insurance Supervisory Authority of Vietnam, and The Office of Insurance Commission of Thailand), a Central Bank (Bank Negara Malaysia, and Monetary Authority of Singapore), and some other Government Agencies (the China Insurance Regulatory Commission, Financial Services Agency of Japan, Financial Supervisory Commission of Taiwan, Financial Services Commission and Financial Supervisory Service of Korea, and Independent Insurance Authority of Hong Kong).

Regulatory minimum capital requirements are a fundamental part of licensed insurers because insurers face uncertainty both as underwriters of risk and as business enterprises. Having sufficient capital is critical to an insurer's ability to meet its obligations to policyholders and creditors and to finance future growth in its business consequently insurance companies must maintain adequate capital requirement. For licensed insurers, the highest minimum paid-up capital is TWD2 billion or USD52 million to meet the FSC's credit rating requirements in Taiwan, and the lowest paid-up capital is HKD10 million or USD1 million for non-life and life insurers in Hong Kong due to Hong Kong liberalizing insurance market requiring no restriction in investment. For Thailand, life insurance companies must maintain THB500 million or USD16 million and non-life insurance companies must maintain THB300 million or USD10 million.

Regulators ensure the insurance companies are in the state of solvency, the insurers has more assets than liabilities and ability to pay benefits and claims in the future. Solvency regulation proposes by Solvency Margin, Risk Based Capital (RBC) and Solvency II have been evolving rapidly across Asian countries. Many regulators have adopted a RBC framework (e.g., Japan, Indonesia, Taiwan, Singapore, Malaysia, South Korea, The Philippines and Thailand). The other countries such as China, Hong Kong, and Vietnam are considering moving 
from Solvency I, based on a solvency margin approach, to an RBC approach. Many companies and regulators in Asia are following the development closely with a view to either seeking regulatory equivalence or implementing various elements of Solvency II in their risk management initiatives (e.g. Japan, Taiwan, South Korea, and Singapore). For Thailand, RBC was established recently in 2011. There are considering Solvency II but not planning implementing soon.

It is important that the policyholders are protected. The policyholder protection funds were already established in most countries providing certain protection for policyholders in the event of insurer insolvency. There is no protection fund for policyholders in Cambodia and Laos-who require deposit protection fund with local government. For Hong Kong, policy protection fund will be set up in 2013-2014.

The liberalization rule for foreign ownership in insurance business leads to gain technology and expertise standardizes policy. Most Asian countries have also liberalized the insurance market, permitting foreign insurers to operate in the domestic market. There are no restrictions on the level of foreign ownership in Hong Kong, Japan, South Korea, Brunei Darussalam, Cambodia, the Philippines, Singapore, and Vietnam. Other countries namely China, Taiwan, Indonesia, Laos, Malaysia, Myanmar, and Thailand, still have foreign ownership restriction but gradually lower the market access restrictions.

\subsection{Thailand Insurance Regulation Highlights}

\subsubsection{Transform Government Regulator}

Previously, the supervision on insurance business of the government sector was the duties and mission of the Department of Insurance, Ministry of Commerce. The roles and responsibility of the Department of Insurance were to encourage an environment that raise the insurance business in Thailand, and to encourage the market to become more competitive in the future. Despite these supportive roles, the Department of Insurance, who was under the supervision of the government with a great deal of red tape, lacked independence authority, causing its inability to serve and support the insurance sectors promptly. Consequently, the transformation of the Department of Insurance into Office of Insurance Commission (OIC) had been carefully planned and supported by the Insurance Commission Act.

Effective from September 1, 2007, all structure and responsibility of the Department of Insurance were transferred to OIC who operating under the supervision of the Ministry of Finance (Office of Insurance Commission, 2012).

\subsubsection{Maintain Capital Requirements}

The target capital requirement is the minimum amount required by the regulator so that insures in Thailand can continue its business. All insurers must maintain capital requirement. Licensed life and non-life insurers are required to raise a minimum paid-up capital of THB500 million and THB300 million, respectively.

Furthermore, all insurance companies must convert to public company status by February 2013. If a company does not converse by, it may continue to operate for a further three years but may not issue new policies. If a company does not convert to public company status by February 2016, the company will lose its license to operate an insurance business in Thailand (Frost, 2012).

\subsubsection{Apply Risk Based Capital (RBC)}

Now, Countries in Asia applying RBC are Japan (since 1997), Indonesia (since 2000), Taiwan (since 2002), Singapore (since 2004), Malaysia (since 2009), South Korea, The Philippines and Thailand (since 2011). The other countries are considering moving from Solvency I, based on a solvency ratio or margin approach, to an RBC approach as China, Hong Kong, and Vietnam.

For Thailand, there is a strengthening of insurance regulation, including solvency modernization by adopting of $\mathrm{RBC}$ solvency systems. This change is occurring alongside the increased focus on consumer protection. All insurance companies are in the place of solvency. This state is interpreted as insurance companies can pay future benefits and claims to policyholders as they come due.

The RBC has been developed to meet the requirements of the Life Insurance Act No. 2, B.E. 2551 and Non-Life Insurance Act No.2, B.E. 2551 which specify that a risk based framework was to be implemented in 2011. The specify framework is as follow.

$$
\text { Capital Adequacy Ratio }(\mathrm{CAR})=\frac{\text { Total Available Capital }}{\text { Risk Capital Requirement }} \times 100 \text { percent }
$$


The CAR is defined as the Total Available Capital divided by the Risk Capital Requirement. The Total Available Capital for insurer is fair assets minus fair liabilities in which assets have been valued at fair or market value and liabilities such as technical reserves have been assessed at an equivalent fair value. Risk Capital Requirement is liabilities on a best estimate basis and plus capital charges for insurance risk, market risk, credit risk and concentration risk.

All insurance companies in Thailand will need to hold solvency margin at a level not lower than a minimum CAR of 125 percent, increasing to 140 percent from 1 January 2013.

\subsubsection{Provide Policyholder Protection: Insurance Fund}

The establishment of policyholder protection funds, officially called Insurance Fund, aims to provide certain protection for policyholders in the event of insurer insolvency. However, the actual structure of the existing funds can differ by insurance type, life and non-life.

Life insurance fund, in accordance to Life Insurance Act, B.E. 2535, amended by the Life Insurance Act No. 2, B.E. 2551, the Management Board of the Fund, with the consent of the Office of Insurance Commission, issues "Rules of the Life Insurance Fund on the Receipt, Payment, and Keeping of the Capital B.E. 2552", which is used to govern and control the management of Life Insurance Fund.

As for non-life insurance fund, in accordance to Non-Life Insurance Act, B.E. 2535, amended by the Non-Life Insurance Act No. 2, B.E. 2551, the management Board of the Fund with the consent of the Office of Insurance Commission, issues "Rules of the Non-Life Insurance Fund on the Receipt, Payment, and Keeping of the Capital B.E. 2552", which is used to govern and control the management of Non-Life Insurance Fund.

In both insurance funds, as well as in the overall insurance fund, there is the same objective. The objective of this policyholder protection fund is to protect the creditor, whose rights are incurred from the insurance liabilities in the event of company bankruptcy or revocation of the life and non-life insurance business license. Insurance fund helps the development of the life insurance business to be solvent and stable (Office of Insurance Commission, 2012).

Prior to claiming from the insurance fund, policyholders must first take a claim against the insurer in insolvency proceedings, the policyholders will have priority over other creditors. Payments are limited to THB 1 million per policyholder.

\subsubsection{Less Strict Foreign Ownership Sharing}

The Thai government has been promoting insurance market to liberalization. In 1998, the government amended its 1992 life and non-life insurance acts and permitted new domestic insurers to form a joint venture with up to 25 percent foreign ownership. This resulted in licensing of 28 new firms, of which 16 was in non-life business, by the year end.

When the 2008 new life and non-life insurance acts became effective, the foreign ownership restriction was eliminated. Now, with approval of the OIC, the government allows foreign equity participation up to 49 percent. The cases that exceed 49 percent must be approved by the Minister of Finance.

\section{Conclusion}

In most Asian countries, the insurance regulations are in development stage. For Thailand, since the regulator was transformed into an independent body in 2007 as OIC and with the implementation of the new Life and Non-Life Acts in 2008, there have been more active supervisions of the insurance market by the governmental regulator.

One of the driving forces for market strength is the introduction of RBC regulation for both life and non-life insurance companies in 2011. In additional, all insurers must maintain capital requirement and convert to public company status by 2016. If a company does not convert by, it will lose its license to operate an insurance business in Thailand. In the event of insurer insolvency, The Life and Non-Life Insurance Fund will provide certain protection for all policyholders within THB1 million payments limitation.

Effective from December 2011, the permitted foreign ownership percentage was increased from 25 percent to 49 percent. The case of ownership above 49 percent must be approved by the Minister of Finance. This permission will facilitate the liberalization of the insurance industry and prepare the Thai market to enter into international competition.

This reforms lead to market strength, promote entrepreneurial freedom, optimize allocation of resources, increase efficiency and bring a better match between supply and demand of insurance. Eventually, the growth of 
insurance activity would promote economic growth.

\section{References}

Frost, S. (2012). Thailand changes foreign ownership rules regarding insurance business. Bangkok International Association.

Kessler, D. (2012). The Future of Insurance Regulation and Supervision-A Global Perspective. The Geneva Paper, 32-36.

Kwon, W. J. (2008). Cross-accountability in Insurance Regulation. Networks Financial Institute paper. Retrieved from http://www.networksfinancialinstitute.org

Kwon, W. J. (2010). A Preliminary Review of Insurance Statistics Sources in Selected Asian Countries. Working paper in OECD-Asia Regional Seminar: Enhancing transparency and monitoring of insurance markets.

Kwon, W. J. (2012). Economic Rationale for Insurance Regulation. The Geneva Paper, 7-20.

Kwon, W. J., Kim, H., \& Lee, S. J. (2005). Can Insurance Firms Easily Exit from the Market? A Global Comparative Analysis of Regulatory Structures. The Geneva Paper, 30, 268-284.

Liedtke, M. P. (2012). Insurance Activity as a Regulatory Object-Trend and Developments and their Appreciation in the Context of Post-Crisis Global Markets. The Geneva Paper, 21-32.

Norton Rose. (2012). Insurance regulation in Asia Pacific. London: Norton Rose Fulbright (Asia) LLP. Retrieved from http://www.nortonrosefulbright.com

Office of Insurance Commission. (2012a). Insurance Development Plan, II(2010-2014). Retrieved from http://www.oic.or.th

Office of Insurance Commission. (2012b). Rules of the Life Insurance Fund On the Receipt, Payment, and Keeping of the Capital B.E. 2552. Retrieved from http://www.oic.or.th

Office of Insurance Commission. (2012c). Rules of the Non-Life Insurance Fund On the Receipt, Payment, and Keeping of the Capital B.E. 2552. Retrieved from http://www.oic.or.th

Outreville, J. F. (1998). Theory and Practice of Insurance. United States of America: Kluwer Academic Publishers. http://dx.doi.org/10.1007/978-1-4615-6187-3

Peltzman, S. (1976). Toward a more General Theory of Regulation. Center for Economic Analysis of Human Behavior and Social Institutions Working Paper No. 133.

Posner, R. A. (1974). Theories of Economic Regulation. The Bell Journal of Economics and Management Science, 5(2), 335-358. http://dx.doi.org/10.2307/3003113

Randall, S. (1999). Insurance Regulation in the United States: Regulatory Federalism and the National Association of Insurance Commissioners. Florida State University Law Review, 625-699.

Schuckmann, S. (2007). The Impact of Solvency II on Insurance Market Competition: An Economic Assessment. Working Paper Series in Finance Paper.

Stigler, G. J. (1971). The Theory of Economic Regulation. The Bell Journal of Economics and Management Science, 2(1), 3-21. http://dx.doi.org/10.2307/3003160

Viscusi, W. K., Vernon, J. M., \& Harrington, J. E. (2000). Economics of Regulation and Antitrust (3rd ed.). Cambridge: MIT Press.

Ziv-Av, D. (2006). Competition versus Regulation in the insurance market: A low and economic analysis of policy and institutes. Master thesis in Law and Economics, University of Hamburg.

\section{Copyrights}

Copyright for this article is retained by the author(s), with first publication rights granted to the journal.

This is an open-access article distributed under the terms and conditions of the Creative Commons Attribution license (http://creativecommons.org/licenses/by/3.0/). 